\title{
Efficiency of Production of Motor Biofuels for Water and Land Transport
}

\section{Učinkovitost proizvodnje motornih biogoriva $u$ vodenom $i$ kopnenom prijevozu}

\author{
Myroslav Panchuk \\ Ivano-Frankivsk National Technical \\ University of Oil and Gas \\ Department of Welding \\ Ukraine \\ e-mail: myroslav_panchuk@ukr.net
}

\author{
Sviatoslav Kryshtopa \\ Ivano-Frankivsk National Technical \\ University of Oil and Gas \\ Department of Automobile Transport \\ Ukraine \\ e-mail: auto.ifntung@ukr.net
}

\author{
Aleksander Sladkowski \\ Silesian University of Technology \\ Faculty of Transport \\ Poland \\ e-mail: aleksander.sladkowski@polsı.pl
}

\author{
Liudmyla Kryshtopa \\ Ivano-Frankivsk National Technical \\ University of Oil and Gas \\ Department of Higher Mathematics \\ e-mail: l.i.kryshtopa@gmail.com
}

\author{
Nataliia Klochko \\ Ivano-Frankivsk National Technical \\ University of Oil and Gas \\ Department of Information and \\ Measuring Technology \\ Ukraine \\ e-mail:dolishnya@gmail.com
}

\author{
Taras Romanyshyn \\ Ivano-Frankivsk National Technical \\ University of Oil and Gas \\ Department of Oil and Gas Equipment \\ Ukraine \\ e-mail: tarasromanushun@gmail.com
}

\author{
Andrii Panchuk \\ Ivano-Frankivsk National Technical \\ University of Oil and Gas \\ Master Student of the Institute of \\ Mechanical Engineering \\ Ukraine \\ e-mail: andrii_panchuk@ukr.net
}

Ilona Mandryk
Ivano-Frankivsk National Technical
University of Oil and Gas
Student of the Institute of
Economics and Management
e-mail: ilonkamandryk1307@ukr.net
DOI $10.17818 / \mathrm{NM} / 2019 / 3.8$

UDK 656.1/.6

62-67

Professional paper / Stručni rad

Rukopis primljen / Paper accepted: 9. 10. 2018.

\section{Summary}

In the article, a qualitative and quantitative analysis of motor biofuels for water and land types of transport is carried out. In that context, the possibility of increasing their efficiency is demonstrated through the introduction of the rapid pyrolysis process, which allows up to $25 \%$ of renewable fuels to be used in a mixture with conventional diesel. It is established that the most effective way is the joint processing of bio-oil with oil products on existing production facilities, which does not require the construction of new plants, significantly reduces the dependence on fossil oil, and the obtained gasoline and diesel fuel have good performance characteristics and their use practically does not require changes in the fuel consumption infrastructure.

\section{Sažetak}

$U$ ovome radu provedena je kvalitativna i kvantitativna analiza motornih biogoriva $u$ vodenom i kopnenom prijevozu. U tom kontekstu prikazuje se mogućnost povećanja učinkovitosti goriva uvođenjem brzog procesa pirolize, kojim se $25 \%$ obnovljivih goriva može koristiti u mješavini s konvencionalnim dizelskim gorivom. Utvrđeno je da je najučinkovitiji način obrada bionafte zajedno s naftnim proizvodima u postojećim proizvodnim pogonima, što ne zahtijeva gradnju novih postrojenja, značajno smanjuje ovisnost o fosilnim gorivima, a dobiveno naftno i dizelsko gorivo pokazuju dobre izvedbene karakteristike, dok njihova uporaba ne zahtijeva promjene $u$ infrastrukturi potrošnje goriva.

\section{KEY WORDS \\ motor fuel \\ pyrolysis \\ bio-oil \\ vacuum gasoil \\ co-processing}

materials in the form of plant biomass creates prerequisites for the development of technologies for motor fuels, alternative to petroleum-based fuels. Biofuels can be used in various types of engines installed on water and land transport. . Filling cars with biofuels is a fairly widespread phenomenon, but the use of biofuels by sea transport is still rather limited is still rather limited and at the same time it is a new solution that has a fairly significant potential and may make up around $10 \%$ of the total amount of marine fuel by 2030 [3, 4]. It should be added that shipping is currently one of the fastest growing and most effective directions in the transport sector and plays an

KLJUČNE RIJEČI
motorno gorivo
piroliza
bionafta
vakuum plinsko ulje
koprocesuriranje
energy demands [2]. The presence of huge natural reserves of renewable raw

\section{INTRODUCTION / Uvod} geothermal and wind power stations that could potentil supplant the production of energy based on fossil fuels [1] Renewable energy allows to organize the self-sufficient and decentralized energy supply and to increase the value of loca resources without dependence on imports, which is especially relevant for those regions where there is no access to modern energy systems or for emerging economies with growing 
important role in the global economy.

Energy production from biomass is developing dynamically in many countries around the world, because the intensive growth of the renewable energy market has not only the energy but also the environmental aspect [5, 6]. Such a strategic direction of energy usage meets the conditions for sustainable development of the planet and the stable economic existence of society.

So, the second-generation biofuels, made from non-food raw materials, have advantage. This direction of development of renewable energy sources has been given increased attention on the side of the leaders of states, representatives of research and public organizations as well as on the side of business, because according to many analysts this is a promising direction of the development of "clean" energy and of eliminating the contradictions between agricultural food industry and energy companies [7].

The sources of raw material for second-generation biofuels are lignocellulose compounds that remain after the parts of plant raw materials, suitable for usage in the food industry, are removed. For this purpose fast-growing trees and grasses (poplar, willow, miscanthus, jatropha, etc.) can be also used. They can grow on slopes, hills, ravines and also on unproductive (marginal) lands sometimes even with the prospect of the restoration of these lands without creating competition with traditional crops [7]. The usage of energy crops also allows the preservation of a forest fund which requires decades to restore. Data on the world potential of biomass reserves are shown in Table 1.

Table 1 Data on the Global Potential of Biomass Reserves [8] Tablica 1. Podaci o globalnom potencijalu rezerva biomase [8]

\begin{tabular}{|l|c|c|}
\hline \multicolumn{1}{|c|}{ Territory } & $\begin{array}{c}\text { Number of products, } \\
\text { (tons of dry biomass } \\
\text { per year) }\end{array}$ & $\begin{array}{c}\text { Boe (barrels of oil } \\
\text { equivalent) }\end{array}$ \\
\hline United States & $1.3 \times 10^{9}$ & $3.8 \times 10^{9}$ \\
\hline Europe & $4.4 \times 10^{8}$ & $1.4 \times 10^{9}$ \\
\hline Africa & $1.1 \times 10^{9}$ & $3.5 \times 10^{9}$ \\
\hline Latin America & $1.1 \times 10^{9}$ & $3.2 \times 10^{9}$ \\
\hline
\end{tabular}

In addition, the economy of agriculture and forest products can be improved through the usage of some of these wastes as is the case with the market for the development of granular fuels for electricity and heating markets.

It should be noted that $90 \%$ of global plant biomass products come from lignocellulose - a heterobiopolymer, consisting of cellulose, various hemicelluloses and lignin [9]. The percentage of lignocellulose components may vary depending on the type of raw material, each of the lignocellulose's components can be used if appropriately treated in the production of biofuels (Table 2).

Unlike other renewable energy sources, biomass is a universal energy source that can be used both for the production of electric and thermal energy and of fuel for transport purposes. However, low energy density, instability of granulometric composition and physical properties of biomass are the main problems of its use.
Table 2 Composition of Some Types of Biomass (Mass Content) [10] Tablica 2. Sastav nekih tipova biomase (udio mase) [10]

\begin{tabular}{|l|c|c|c|}
\hline \multicolumn{1}{|c|}{ Biomass } & Cellulose, $\%$ & Hemicellulose, $\%$ & Lignin, $\%$ \\
\hline Wheat straw & 30 & 50 & 15 \\
\hline Rice straw & 32.1 & 24 & 18 \\
\hline Corn cobs & 45 & 35 & 15 \\
\hline Millet & 45 & 31.4 & 12.0 \\
\hline Willow & 49.3 & 31.4 & 12.0 \\
\hline Birch & 40 & 26 & 16 \\
\hline Pine & $45-50$ & $19-22$ & $21-29$ \\
\hline Trees leaves & $15-20$ & $80-85$ & 0 \\
\hline $\begin{array}{l}\text { Herbs (average } \\
\text { for herbs) }\end{array}$ & $25-40$ & $25-40$ & $10-30$ \\
\hline
\end{tabular}

Biomass in the initial state has a wide distribution of moisture content (25-60\%), uneven size of parts (10-100 mm) and low energy density. In this regard, there are difficulties in its storage and transportation. The low bulk density (60-200 kg/ $\mathrm{m}^{3}$ ) of lignocellulosic biomass further increases the cost of its transporting and storing. All these reasons limit the usage of biomass [11].

In order to more efficiently and economically use biomass as a raw material for the production of transport fuels it is necessary to improve its consumer properties. One of the effective methods of preliminary processing and modification of the physical properties of biomass can be the process of pyrolysis [12].

\section{FEATURES OF THE PYROLYSIS PROCESS / Karakteristike procesa pirolize}

It is known that pyrolysis technologies were used more than 5500 years ago in Southern Europe and in the Near East for the extraction of charcoal. Pyrolysis was also used to produce various resins and embalming agents in Ancient Egypt. In its turn, the use of charcoal allowed to provide necessary conditions for melting tin and copper and producing bronze [13].

Depending on the operating conditions pyrolysis can be divided into two main categories: slow and fast [14]. They are characterized by the temperature of the process, the heating rate, the time of the process, the size of the biomass particles, etc. The primary products of pyrolysis are pyrolysis liquid, a solid carbon substance and gases, and the relative yield of products depends on the technological parameters of the pyrolysis process. For this reason, slow pyrolysis is one of the most effective methods for converting biomass to charcoal and rapid pyrolysis makes it possible to obtain the maximum amount of liquid phase which is also called bio-oil.

Fast pyrolysis benefits from low investment and the ability to get a liquid end product that can be transported and converted into motor fuels and valuable products on the technology lines fully compatible with the existing oil infrastructure [15]. It provides significant economic benefits over ethanol, which requires significant technical and material costs for pre- 
Table 3 Comparison of Characteristics of Different Fuels

Tablica 3. Usporedba karakteristika različitih goriva

\begin{tabular}{|l|c|c|c|c|c|}
\hline \multicolumn{1}{|c|}{ Characteristics } & Unit & Wood [18] & $\begin{array}{c}\text { Wood } \\
\text { Pallets [18] }\end{array}$ & $\begin{array}{c}\text { Wheat Straw } \\
\text { in Bundles[19] }\end{array}$ & Straw Pallets [19] \\
\hline Burn heat of combustion & $\mathrm{MJ} / \mathrm{kg}$ & $9-12$ & $15-16$ & 14.4 & $14-15$ \\
\hline Density & $\mathrm{kg} / \mathrm{dm}^{3}$ & $0.2-0.25$ & $0.55-0.75$ & $0.07-0.16$ & $0.500-0.70$ \\
\hline Volume density of energy & $\mathrm{MJ} / \mathrm{dm}^{3}$ & $2.0-3.0$ & $7.5-10.4$ & $1.01-2.3$ & $7.75-11.2$ \\
\hline The cost of transportation & & High & Moderate & High & Moderate \\
\hline
\end{tabular}

production of raw materials and requires the development of parallel infrastructure.

In addition, the by-products of pyrolysis have their rational use. Pyrolysis gas can be used as an additional energy for drying inbound biomass and reactor operation [16], while black ash charcoal can be used as fuel and fertilizers for soil [17].

As can be seen in Table 3, due to its high density, the biooil has lower transport costs compared to cut or compressed biomass types which allows it to be delivered at long distances at a reduced cost, to increase the optimum size of production capacities of biologically pure fuel and to reduce the cost of a unit of received motor fuel.

The data presented in Table 3 are proved by the results of the work [21], that the unit cost of transporting untreated biomass is about 0.44 dollars per ton per kilometre while the cost of transportation of bio-oil is about 0.09 dollars per ton per kilometre.

Thus, it can be concluded that the pyrolysis process is an effective way of converting lignocellulosic raw materials into liquid bio-oil, the use of which can play a significant role in modelling processing plants and expand the options for the production of transport fuels.

\section{BIO-OIL AND ITS PROPERTIES / Bio-nafta $i$ njezina svojstva}

Bio-oil is a highly oxidized hydrocarbon with significant water content (both initial and formed as a result of the reaction) and the unwanted impurities of a solid carbonaceous substance, whose ash content is 0.13 (compared to 0.01 for diesel and 0.03 for heavy fuel oil) [22].

The elemental composition of bio-oil and its viscosity differ significantly from oil fuels (Table 4 ) and its combustion heat is in the range of $16-18 \mathrm{MJ} / \mathrm{kg}$, compared to $42.9 \mathrm{MJ} / \mathrm{kg}$ for motor diesel and $40.7 \mathrm{MJ} / \mathrm{kg}$ for boiler fuel - heavy fuel oil. Water content in the bio-oil is 20-30\% and in heavy fuel oil and diesel fuel it is less than $0.1 \%$.

The increased acidity of bio-oil generates corrosion of certain systems during its storage and requires the use of corrosion-resistant materials. In addition, bio-oil is characterized by instability and can change its properties (increase in viscosity, phase separation, formation of sediments) over time, the same happens when it is in contact with warm air [23].

Thus, low calorific value, high water and oxygen content, incompatibility with traditional petroleum fuels, presence of impurities of solids, high acidity and viscosity, chemical instability adversely affect the quality of bio-oil, and its usage as transport fuel needs to be improved.

For this purpose, depending on the functional use of biooil, physical and chemical methods can be used. The first of them is the high-temperature filtration of liquid or vapour to eliminate coal particles, mixing bio-oil with solvents and hydrocarbons (diesel fuel). Chemical methods include: catalytic deoxygenation (removal of oxygen) in the presence of hydrogen, hydrogenation, cracking in the vapour phase, on zeolite catalysts, etc. [24].

For marine fuel applications, pyrolysis oil can be used as a component in emulsion biofuels to increase their thermal efficiency and reduce particulate emissions when used in diesel engines [25]. Emulsifying pyrolysis oils can not only enhance the stability of the fuel, the addition of emulsifiers (surfactants) can act as viscosity modifiers to create more optimal fuel properties.

\section{WAYS OF OBTAINING TRANSPORT BIOFUELS ON THE BASIS OF PYROLYSIS / Načini dobivanja biogoriva za prijevoz s pomoću pirolize}

Currently the following ways of production of transport biofuels on the basis of pyrolysis are considered [26]:

- chemical upgrading of bio-oil;

- joint processing of bio-oil with petroleum products at the refinery;

the bio-oil, obtained from the pyrolysis, is sent for gasification and subsequently subjected to the synthesis of the Fischer-Tropsch process.

Table 4 Comparative Characteristics of Bio-oil and Traditional Liquid Fuels [20]

Tablica 4. Komparativne karakteristike bionafte i tradicionalnih tekućih goriva [20]

\begin{tabular}{|l|c|c|c|c|}
\hline \multicolumn{1}{|c|}{ Parameters } & Unit & Bio-oil & Diesel fuel & Heavy fuel oil \\
\hline Density (at 15 ${ }^{\circ} \mathrm{C}$ ) & $\mathrm{kg} / \mathrm{dm}^{3}$ & 1.22 & 0.850 & 0.960 \\
\hline Kinematic viscosity @ 50 & $\mathrm{\circ} \mathrm{C}$ & 13 & 2.5 & 351 \\
\hline Lower heating value & $\mathrm{MJ} / \mathrm{kg}$ & 17.5 & 42.9 & 40.7 \\
\hline Ash & $\% \mathrm{wt}$ & 0.13 & $<0.01$ & 0.03 \\
\hline Water content & $\% \mathrm{wt}$ & 20.5 & 0.1 & 0.1 \\
\hline Elemental analysis & $\%$ & & & \\
Carbon & $\%$ & 48.5 & 86.3 & 86.1 \\
Hydrogen & $\%$ & 42.5 & 12.8 & 0.8 \\
\hline $\begin{array}{l}\text { Oxygen } \\
\text { Sulphur }\end{array}$ & $\%$ & 0 & $0.15 \ldots 0.30$ & 2.1 \\
\hline
\end{tabular}




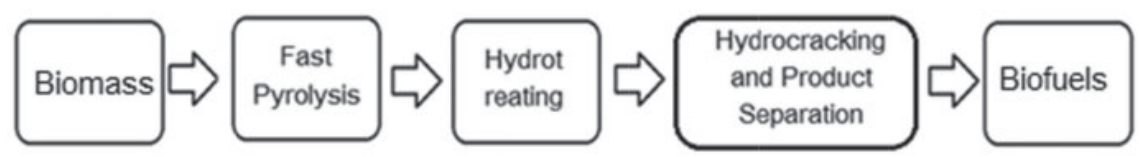

Figure 1 Scheme of converting biomass into liquid fuels by upgrading the bio-oil Slika 1. Prikaz pretvaranja biomase u tekuća goriva poboljšanjem bionafte

\subsection{Producing Transport Biofuels by the Chemical Upgrading of Bio-Oil / Proizvodnja transportnih biogoriva s pomoću kemijskog poboljšanja bionafte}

One of the most promising ways for biofuels production is the direct upgrading of bio-oil, produced by fast pyrolysis. Such technology includes the upgrading of bio-oil by hydrotreating to the minimum oxygen content and hydrocracking of the heavy part of the upgraded liquid. After that the distillation of the resulting mixture and its separation into gasoline and diesel fuel are carried out. The scheme of the process is represented in Figure 1.

Removing oxygen from liquid pyrolysis products is based on using the zeolite cracking or hydrooxenization [27].

Zeolite cracking is based on using synthetic zeolite. It is also widely used in alcohol production. Zeolites are water aluminosilicates of sodium and calcium. To improve the quality of bio-oil the zeolite cracking of pyrolysis vapour is used, in which zeolite acts as a catalyst. In this case, oxygen from the biooil is removed in the form of $\mathrm{CO}, \mathrm{CO}_{2}$ and $\mathrm{H}_{2} \mathrm{O}$. Zeolite cracking is recommended to be carried out directly in the formation of pyrolysis vapour, i.e. adding a catalyst to a pyrolysis reactor. This is due to the fact that it is rather difficult to transfer the condensed bio-oil into a steam phase and in thermal action it can decompose into other chemical compounds [28]. Similar approach is implemented in the pilot project [29], in which primary processing of bio-oil is performed in a separate block of the pyrolysis reactor with the aid of catalyst and occurs before the condensation of vapours. The authors also report that this technology served the basis for obtaining transport gasoline.

The benefit of zeolite cracking is low capital costs due to the relatively low cost of the reactor that has an increased throughput and operates at low pressure. At the same time, during this process the amount of oxygen is reduced, which affects the output and the quality of transport fuels.

Hydrodeoxygenation (HDO) is a process of hydrogenolysis that removes oxygen from raw materials at a temperature of $300-400^{\circ} \mathrm{C}$ and pressure of $150-300$ bar. The carbon-oxygen compounds are cleaved with hydrogen, in the presence of the catalyst that produces $\mathrm{CO}_{2}$ and $\mathrm{H}_{2} \mathrm{O}$ and partially eliminates oxygen from the final product. The presence of water in the process of hydrotreating is important to prevent the formation of a solid carbon layer.

The general equation of hydroxygenation can be represented in the following form:

$$
-\left(\mathrm{CH}_{X} \mathrm{O}_{Y}\right)-+\mathrm{CH}_{2}=-\left(\mathrm{CH}_{X}\right)-+\left(\mathrm{H}_{2} \mathrm{O}, \mathrm{CO}_{2}, \mathrm{CH}_{4}, \mathrm{CO}\right)
$$

With HDO one can get a high-quality, energy-intensive, inorganic product with the percentage of oxygen less than $2 \%$, which can be also upgraded to other chemicals. However, this method has the main drawback - a large amount of hydrogen $600-1000 \mathrm{l} / \mathrm{kg}$ in the presence of high pressure, which increases the cost of production [30]. It is important to note that the high consumption of hydrogen is also typical of the processes of the traditional oil refining industry.

The authors [31] report that it is expedient to conduct hydrotreating in three stages: stabilization, mild and moderate stages of hydroxygenation. At each subsequent stage, the degree of bio-oil refining increases without causing significant catalyst deactivation. The first stage is stabilization - mild hydrotreating at a temperature of $140^{\circ} \mathrm{C}$, using a rutheniumbased catalyst, which reduces the reactivity of some components. The second reactor contains a ruthenium-based catalyst and operates at an elevated temperature of $252^{\circ} \mathrm{C}$, and the last third reactor contains a molybdenum-based catalyst and operates at a temperature of $400^{\circ} \mathrm{C}$ which allows for almost complete oxygen removal.

After the completion of the second stage of hydroxygenation, the product is divided into components: waste gas streams, waste water and oils. After this the waste gases can be used to produce hydrogen.

The refined modernized oils are stabilized by removing butane and lighter components during distillation, then a constant oil flow is divided into light and heavy fractions. In this case, a heavy fraction with a boiling point above $350^{\circ} \mathrm{C}\left(662^{\circ} \mathrm{F}\right)$ is directed to a hydrocracker for the complete conversion of oil into a mixture of components of gasoline and diesel fuel.

The resulting product is a mixture of fluids that cover gasoline and diesel ranges and some by-products. Gasoline and diesel products are separated by distillation. These products are used for mixing in the ready fuel.

The research, carried out by BTG staff together with the scientists from the University of Twente, has shown that $25 \%$ of biodiesel obtained through direct upgrading can be mixed with $75 \%$ of conventional diesel, and the resulting mixture can be successfully used to fuel the automobiles [32].

\subsection{Co-Processing of Bio-Oil with Petroleum Products in the Conditions of the Oil-Refinery Plant / Koprocesuiranje bionafte naftnim proizvodima u naftnoj rafineriji}

At present, the co-processing of renewable and natural raw materials on standard oil refining equipment is of special interest. One of the ways of co-processing bio-oil with fossil fuels is fluid catalytic cracking (FCC).

Fluid catalytic cracking is one of the main processes of secondary processing of oil, which allows to get high-quality products, including automotive gasoline and diesel fuel. Installing catalytic cracking is often the main element of the refinery. The purpose of the process is to "split" the gas oil fraction after distillation. Cracking is carried out with the aid of a catalyst, aerated by steam and acting as a liquid. Catalytic cracking refers to the most extensive processes in the developed countries of the world, such as the USA, Arab Emirates, Great Britain, and makes up to $35 \%$ of the capacity of primary processing of crude oil [34].

The co-processing is the simultaneous transformation of renewable raw materials, bio-oil, and intermediate petroleum 


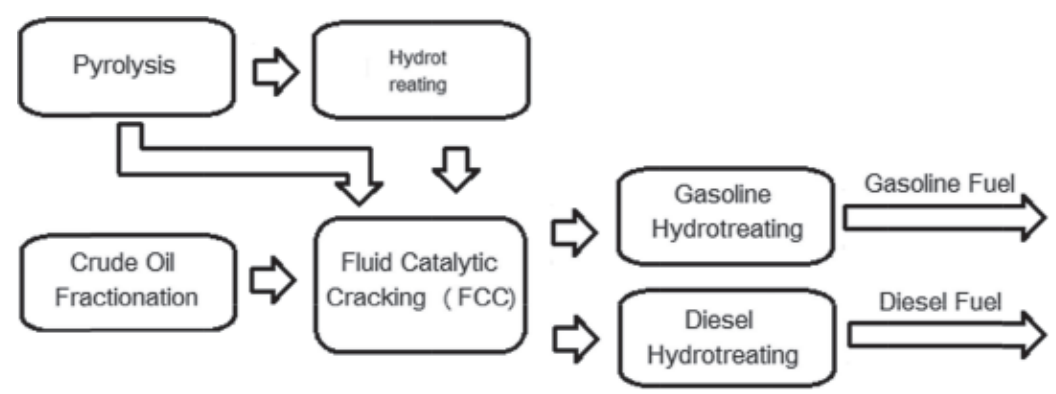

Figure 2 Scheme of the FCC process for co-processing

Slika 2. Prikaz FCC procesa za koprocesuiranje

products, such as vacuum gas oil (VGO), using process plants at the existing oil refinery (Figure 2).

The co-processing in FCC blocks is a new and promising way of converting bio-oil into renewable gasoline and diesel fuel. Current studies are mainly aimed at revealing the potential of this technology and suggest that the coprocessing can provide significant potential for using the existing processing infrastructure for the processing of biomass, mainly lignocellulosic raw materials, and increase the supply of bio-oil to the market [34, 35].

For example, in the United States there are currently 110 liquid catalytic cracking plants, that could produce over eight billion gallons of biofuel (over 30 billion litres) based on the existing oil refineries infrastructure [29].

The authors [36] conducted research and established the technical ability to directly use up to $20 \%$ of crude bio-oil for the co-processing on the FCC units. However, it is reported that in this case there arise a number of technical problems [37]. In particular, some bio-oil is converted into coke, oil gas (LPG), carbon dioxide, carbon monoxide and water vapour, which, in general, reduces the output of transport fuels, and the increased amount of oxides and phenol groups negatively affects their quality. Testing this fuel in engines revealed the increased amount of gaseous emissions [38].

The authors [39] show that it is possible to improve the output of renewable gasoline if crude bio-oil is subjected to the hydrodeoxyation process. During their research, they found out that the co-processing of $20 \%$ of the biooil subjected to HDO with $80 \%$ of VGO led to the level of gasoline output comparable to the processing of traditional raw materials - the cracking of pure VGO. Similar results were obtained in the work by Lindfors [40], in which hydrogenated pyrolysis oil yielded $74 \%$ by weight of liquid products compared to $69 \%$ (dry pyrolysis oil) for untreated liquid (Table 5). The resulting gasoline is characterized by good performance characteristics similar to the traditional processing of pure vacuum gas oil and their use does not require any changes in the fuel consumption infrastructure.

The fuel obtained by co-processing has good performance characteristics, similar to those obtained through processing pure vacuum gas oil, and its use practically does not require changes in the infrastructure of fuel consumption of the engine [41]. Such advantages can be substantial enough for engines of sea ships, the new fuels for which require considerable financial expenses.

It should be noted that the technology of co-processing biooil and secondary petroleum products under the conditions of the oil refining plant on the operating equipment is at the initial stage of study. Therefore, carrying out further researches will allow to improve the process of co-processing and to find the optimal parameters of bio-oil for its delivery to the oil refinery.

Table 5 Impact of Upgrading Pyrolysis Oil on Liquid Product Yields [40]

Tablica 5. Učinak poboljšanja nafte nakon pirolize na prinos tekućih proizvoda [40]

\begin{tabular}{|l|c|c|c|c|}
\hline Products & Unit & VGO & $\begin{array}{c}\text { VGO + 20\% dry } \\
\text { pyrolysis oil }\end{array}$ & VGO + 20\% HDO \\
\hline Liquid & $\% \mathrm{wt}$ & 85 & 69 & 74 \\
\hline Gas & $\% \mathrm{wt}$ & 10 & 14 & 12 \\
\hline Precipitate & $\% \mathrm{wt}$ & 5 & 10 & 10 \\
\hline
\end{tabular}

\subsection{Using Bio-Oil for Gasification and Further} Conversion into Biofuels using Fischer-Tropsch synthesis / Uporaba bionafte za uplinjavanje i daljnju konverziju biogoriva uporabom Fischer-Tropsch sinteze

Biomass can be converted into synthesis gas directly through the gasification process or indirectly: first of all, biomass undergoes fast pyrolysis to produce bio-oil which is later gasified to produce gas synthesis and subsequently subjected to the Fischer-Tropsch synthesis (Fig. 3).

Compared to the gasification of solid fuel, the synthesis of gas from liquid fuel has the following main advantages [42]:

- the synthesis gas, made from bio-oil, has a better quality, since it produces fewer compounds of resins than direct gasification;

- the efficiency of plants during the gasification of liquid fuels is higher than during the gasification of solid fuel;

the gasification process of liquid fuels can be fully automated, which minimizes the number of maintenance staff;

- in case of operation on liquid raw materials, the gas output per $1 \mathrm{~m}^{3}$ of the reaction space is much higher than during the operation on solid fuels;

when processing liquid fuels from the process flow, such complex and cumbersome units as fuel preparation, fuel supply and sludge removal are excluded;

- the gasification unit of liquid fuels is more compact than the gasification unit of solid fuels and requires less investment per unit of produced gas.

The above advantages make this method of synthesis gas production quite promising.

Depending on the conditions of the process and the catalyst used, liquid hydrocarbons, including synthetic gasoline, diesel fuel, high-quality lubricants, paraffin and other valuable 


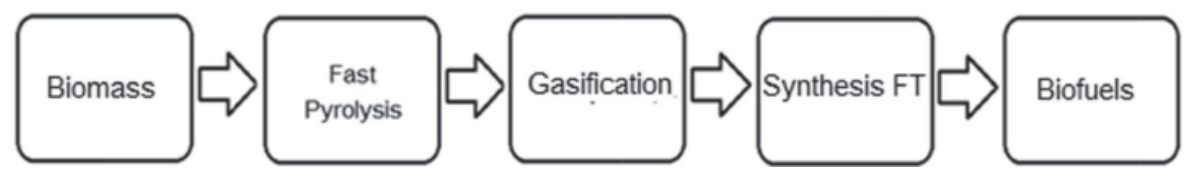

Figure 3 Scheme of the Gasification Process of Biomass on Liquid Fuels Slika 3. Prikaz procesa uplinjavanja biomase pri tekućim gorivima

products, can be obtained using the Fischer-Tropsch synthesis.

It should be noted that the hydrocarbons, obtained by the Fischer-Tropsch synthesis, have a high content of paraffins and do not contain aromatic substances or sulphur, they burn more purely than petroleum fuels, generating lower emissions of $\mathrm{NO}_{x}, \mathrm{SO}_{x}$ and particles. This reduces engine noise and wears of of its important components. Fischer-Tropsch synthesized fuels are fully compatible with the existing infrastructure and engines, which is problematic for other types of alternative fuels. Due to its high performance, namely the cetane number, which is about 70 (while for petroleum fuels it ranges from 45 to 55), they are often mixed with petroleum diesel to improve its quality. Nowadays the process of gasification and the synthesis of Fisher Tropash need significant investment in the creation of new enterprises and infrastructure which entails high prices for the received motor fuel.

\section{EFFICIENCY OF THE THERMOCHEMICAL METHODS OF PRODUCING TRANSPORT BIOFUELS / Učinkovitost termokemijskih metoda proizvodnje biogoriva za prijevoz}

Based on the feasibility study, it is known that the oil refining industry is characterized by large oil refining plants. This situation is due to the fact that the operating costs of the plants are defined by the economy of scale, which characterizes the slower growth of operating costs of the enterprise with increased capacity. Thus, it is obvious that the cost of the unit of motor fuels from the sources of fossil fuels decreases with the increasing productivity of the processing enterprise.

In case of biomass processing, the same tendency is observed - in case of a sufficient amount of raw materials, the production and modification of bio-oil can be effectively carried out in one large enterprise. However, it should be noted that unlike fossil fuels, the biomass has a rather wide territorial distribution and a relatively low annual yield (usually less than 10 tons per hectare (dry and without ash)), which leads to the rising cost of finished products due to the long-distance delivery of raw materials [21].

Therefore, in this case it would be advisable to carry out a separate processing - bio-oil is obtained at the primary plant with subsequent transportation to the main large enterprise for the production of biofuels according to one of the abovementioned methods. The research work [43] reports about the potential for using mobile reactors of fast pyrolysis for the processing of processing biomass on economically feasible small scale, which can be used in distributed processing systems. The produced bio-oil can be delivered to the end user both by transport vehicles and by means of pipelines. Minimizing the transportation costs by moving the pyrolysis production to the location of raw materials reduces biomass costs to minimum.

It is worth noting that the diversity of chemical and physical properties of bio-oil and the insufficient information on them make it difficult to find the only optimal integrated method of processing it into biofuels. At the same time, the prices of transport biofuels, obtained by the above-mentioned technologies, are shown in Table 6.

Table 6 Prices of Transport Biofuels Obtained by Different Technologies

Tablica 6. Cijene biogoriva za prijevoz prikupljenih raznim tehnologijama

\begin{tabular}{|l|c|c|}
\hline \multicolumn{1}{|c|}{ Products } & $\begin{array}{c}\text { Unit of } \\
\text { measurement }\end{array}$ & Price \\
\hline Chemical upgrading of bio-oil [44] & Dollar/gallon & 2.04 \\
\hline Co-processing at oil-refinery [44] & Dollar/gallon & 1.74 \\
\hline $\begin{array}{l}\text { Gasification using the Fischer-Tropsch } \\
\text { process [45] }\end{array}$ & Dollar/gallon & 3.6 \\
\hline
\end{tabular}

Having analyzed the data in Table 6, we can make a conclusion that in terms of economic efficiency, the coprocessing of bio-oil and petroleum products at refineries is at present an effective solution and may pave the way for the introduction of biofuels into the market, since in addition to the lowest price per unit of production it decreases the environmental impact of fossil fuels [46], reduces the countries' dependence on oil and, most importantly, uses the existing facilities, avoiding the construction of new plants. It should be noted that the construction of a new fuel plant can last for five years, while the existing refineries can be reconstructed in less than a year.

\section{CONCLUSIONS / Zaključci}

1. The use of fast pyrolysis process for the preliminary processing and modification of the physical properties of lignocellulosic biomass allows obtaining the bio-oil, which is considered to be a universal raw material for manufacturing second-generation biofuels, which do not compete with food resources, and an effective material for energy transportation.

2 . In the case of the production of transport fuels the biooil must be chemically modified or "upgraded" by removing and converting the undesirable compounds, most of which contain oxygen.

3. In the case of marine engines, the bio-oil can be efficiently used as a component of emulsion biofuels, which increases their thermal efficiency and reduces greenhouse gas emissions.

4. Biodiesel, obtained by the direct upgrading of $25 \%$ of biodiesel, can be mixed with conventional diesel, and the resulting mixture can be successfully used to refuel engines.

5. Nowadays the most effective way of obtaining motor fuels for water and land transport may be the co-processing of bio-oil with the mixture of petroleum products, which does not require the construction of new plants, reduces the dependence on fossil oil and may pave the way for the intensive introduction of biofuels into the market. The resulting biofuels have good operational characteristics and their use practically does not require changes in the fuel consumption infrastructure. 


\section{REFERENCES / Literatura}

[1] Chryssakis, C., Balland, O., Tvete, H. A., Brandsæter, A. (2014). "Alternative Fuels for Shipping". DNV GL Strategic Research \& Innovation, Position Paper.

[2] Ryan, L., Convery, F., Ferreira, S. (2006). "Stimulating the use of biofuels in the European Union: Implications for climate change policy". Energy Policy, Vol. 34 No 17, pp. 3184-3194. https://doi.org/10.1016/j.enpol.2005.06.010

[3] Tyrovola, T., Dodos, G. S., Kalligeros, S., Zannikos, F. (2017). "The Introduction of Biofuels in Marine Sector". Journal of Environmental Science and Engineering A6, pp. 415-421. https://doi.org/10.17265/2162-5298/2017.08.006

[4] Rahman, A., Mashud, K. (2015). "Overview of Alternative Fuels and Their Drivers to Reduce Emissions in the Shipping Industry". In: International Conference on Mechanical and Industrial Engineering (ICMAIE' 2015), Kuala Lumpur. https://doi. org/10.15242/iae.iae0215216

[5] Kryshtopa, S., Panchuk, M., Dolishnii, B., Kryshtopa, L., Hnyp, M., Skalatska, O. (2018). "Research into emissions of nitrogen oxides when converting the diesel engines to alternative fuels". Eastern-European journal of enterprise technologies, Vol. 1, No. 10 (91), pp. 16-22. https://doi.org/10.15587/1729-4061.2018.124045

[6] Kryshtopa, S., Panchuk, M., Kozak, F., Dolishnii, B., Mykytii, I., Hnyp, M., Skalatska, O. (2018). "Fuel ekonomic raising of alternative fuel converted diesel engines". Eastern-European journal of enterprise technologies, Vol. 4, No. 8 (94), pp. 6-13. https://doi.org/10.15587/1729-4061.2018.139358

[7] Panchuk, M., Kryshtopa, S., Shlapak, L., Kryshtopa, L., Yarovyi, V., Sladkovskyi, A (2017). "Main trend of biofuels Production in Ukraine". Transport Problems, Vol. 12, No. 4, pp. 95-103. DOI: 10.20858/tp.2017.12.4.2

[8] Huber, G. W., Iborra, S., Corma, A. (2006). "Synthesis of transportation fuels from biomass: chemistry, catalysts, and engineering". Chemical Reviews, Vol. 106 (9), pp. 4044-4098. https://doi.org/10.1021/cr068360d

[9] Steen, E. V., Claeys, M. (2008). "Fischer-Tropsch catalysts for the biomass-toliquid (BTL) process". Chem. Eng. Technol., Vol. 31, No. 5, pp. 655-660.https://doi org/10.1002/ceat.200800067

[10] Howard, R. L., Abotsi, E., Jansen van Rensburg, E. L., Howard, S. (2003). "Lignocellulose biotechnology issues of bioconversion and enzyme production". Afr. J. Biotechnol, Vol. 2, No. 12, pp. 602-619. https://doi. org/10.5897/ajb2003.000-1115

[11] Makarov, A. A., Pushkin, S. A., Grachev, A. N., Bashkirov, A. N. (2013) "Investigation of fuel properties of solid products of thermal decomposition in the temperature range $200-300^{\circledR} C^{\prime \prime}$. Bulletin of the Technological University, No. 19 , pp. 133-134. (in Russian)

[12] Venderbosch, R. H., Prins, W. (2010). "Fast pyrolysis technology development". Biofuels, Bioproducts and Biorefining, Vol. 4, No. 2, pp. 178-208. https://doi. org/10.1002/bbb.205

[13] Mohan, D., Pittman, C. U., Steele, P. H. (2006)."Pyrolysis of wood/biomass for biooil: a critical review". Energy Fuels, Vol. 20, pp. 848-889. https://doi.org/10.1021/ ef0502397

[14] Basu, P. (2010). Biomass gasification and pyrolysis: practical design and theory. Kidlington, Oxford: Academic Press.

[15] Vispute, T. P., Zhang, H., Sanna, A., Xiao, R., Huber, G. W. (2010). “Renewable chemical commodity feedstocks from integrated catalytic processing of pyrolysis oils". Science, Vol. 330, pp. 1222-1227. https://doi.org/10.1126/ science.1194218

[16] Balat, M., Kirtay, E., Balat, H. (2009). "Main routes for the thermo-conversion of biomass into fuels and chemicals. Part 1: Pyrolysis systems". Energy Convers. Manag, Vol. 50, pp. 3147-3157. https://doi.org/10.1016/j. enconman.2009.08.014

[17] Lehmann, J., Rillig, M. C., Thies, J., Masiello, C. A., Hockaday, W. C., Crowley, D. (2011). "Biochar effects on soil biota: A review". Soil Biol. Biochem., Vol. 43, pp. 1812-1836. https://doi.org/10.1016/j.soilbio.2011.04.022

[18] Kaltschmitt, M., Hartmann, H., Hofbauer, H. (2009). Energie aus Biomasse, 2. Auflage. Springer. https://doi.org/10.1007/978-3-540-85095-3

[19] Geletukha, G., Dragnev, S., Kucheruk, P., Matveiev, Y. (2017). "Practical manual for representatives of the agro-industrial complex on the use of biomass as a fuel in the municipal sector". http://www.uabio.org/img/files/docs/biofin.pdf (in Ukrainian)

[20] Vivarelli, S., Tondi, G. (2004). “Pyrolysis Oil: Innovative Liquid Biofuel for Heating. The COMBIO Project". Presentation at Int. Workshop "Bioenergy for a sustainable development", Casino Vina del Mar - Chile, 8-9 November 2004.

[21] Zheng, J.-L., Zhu, M.-Q., Wen, J.-L., Wu, H.-T., Run-Cang, S. (2016). “Opportunities for Production of Biosynfuels via Bio-Oil Gasification". Research \& Reviews: Journal of Microbiology and Biotechnology, Vol. 5, No. 4.

[22] Demirbas, A. (2007). “The influence of temperature on the yields of compounds existing in bio-oils obtained from biomass samples via pyrolysis". Fuel Proc Technol,Vol. 88, No. 6, pp. 591-597. https://doi.org/10.1016/j.fuproc.2007.01.010

[23] Oasmaa, A., Meier, D. (2005). "Norms and standards for fast pyrolysis liquids: 1. Round robin test". J. Anal. Appl. Pyrol., Vol. 73, No. 2, pp. 323-334. https://doi. org/10.1016/j.jaap.2005.03.003

[24] Zacher, A. H., Olarte, M. V., Santosa, D. M., Elliott, D. C., Jones, S. B. (2014). "A review and perspective of recent bio-oil hydrotreating research". Green Chem.,
Vol. 16, pp. 491-515. https://doi.org/10.1039/c3gc41382a

[25] Ochoterena, R., Lif, A., Nydén, M., Andersson, S., Denbratt, I. (2010). “Optical studies of spray development and combustion of water-in-diesel emulsion and microemulsion fuels". Fuel, Vol. 89, pp. 122-132. https://doi.org/10.1016/j. fuel.2009.06.039. https://doi.org/10.1016/j.fuel.2009.06.039

[26] Huber, G. W., Corma, A. (2007). "Synergies between bio- and oil refineries for the production of fuels from biomass". Angew. Chem. Int. Ed. Engl., Vol. 46, No. 38, pp. 7184-7201. https://doi.org/10.1002/anie.200604504

[27] Bridgwater, A. V. (1989). "Biomass Pyrolysis Technologies". Proc. of the 5th European Bioenergy Conference. Lisbon, Portugal, 9-13 October 1989, Vol. 2, pp. 489-496.

[28] Williams, P. T., Nugranad N. (1998). "Aromatic Hydrocarbons in the Catalytic Upgrading of Biomass Pyrolysis Oils in the Presence of Steam". Proc. of the 10th European Bioenergy Conference, Wurzburg, Germany, 8-11 June 1998, pp. 15891592.

[29] New Pilot Plant Demonstrates the Potential to Co-Process Biomass Streams with Petroleum (2016). https://energy.gov/eere/bioenergy/articles/new-pilotplant-demonstrates-potential-coprocess-biomass-streams-petroleum.

[30] Bridgwater, A. V. (2012). "Review of fast pyrolysis of biomass and product upgrading". Biomass and Bioenergy, Vol. 38, pp. 68-94. https://doi.org/10.1016/j. biombioe.2011.01.048

[31] Elliott, D.C. (2007). “Historical developments in hydroprocessing bio-oils". Energy and Fuels, Vol. 21, No. 3, pp. 1792-1815. https://doi.org/10.1021/ef070044u

[32] Press release BTG: World's first car ride on diesel fuel from wood residues (2013). http://www.btgworld.com/en/news/article?id=105

[33] Leffler, W. L. (2008). Petroleum refining in Nontechnical Language. Tulsa, Oklachoma, USA: Pen Well Corp.

[34] Freeman, C. J., Jones, S. B., Padmaperuma, A. B., Santosa, M., Valkenburg, C., Shinn, J. (2013)..'Initial assessment of US refineries for purposes of potential bio-based oil insertions. Pacific Northwest National Laboratory, Richland, WA United States. https://doi.org/10.2172/1097335

[35] Hsieh, C. C, Felby, C. (2017). "Biofuels for the marine shipping sector". University of Copenhagen, IEA Bioenergy, Task 39. http://task39.sites.olt.ubc.ca/ files/2013/05/Marine-biofuel-report-final-Oct-2017.pdf

[36] De Rezende Pinho, A., De Almeida, M. B., Mendes, F. L., Casavechia, L. C., Talmadge, M. S., Kinchin, C. M., Chum, H. L. (2017). "Fast pyrolysis oil from pinewood chips co-processing with vacuum gas oil in an FCC unit for second generation fuel production". Fuel, Vol. 188, pp. 462-473. https://doi. org/10.1016/j.fuel.2016.10.032

[37] Marker, T. L. (2005). "Opportunities for biorenewables in oil refineries". Department of Energy Washington, USA. Final Tech. Rep. DE-FG36-05GO15085.

[38] Baumgardner, M. E., Vaughn, T. L., Lakshminarayanan, A., Olsen, D., Ratcliff, M. A., McCormick, R. L., Marchese, A. J. (2015). "Combustion of Lignocellulosic Biomass Based Oxygenated Components in a Compression Ignition Engine". Energy Fuels, Vol. 29, No. 11, pp. 7317-7326. https://doi.org/10.1021/acs. energyfuels.5b01595

[39] Fogassy, G., Thegarid, N., Thoussaint, G., van Veen, A. C., Schuurman, Y., Mirodatos, C. (2010). "Biomass derived feedstock co-processing with vacuum gas oil for second-generation fuel production in FCC units". Applied Catalysis B: Environmental, Vol. 96, No. 3, pp. 476-485. https://doi.org/10.1016/j. apcatb.2010.03.008

[40] Lindfors, C., Paasikallio, V., Kuoppala, E., Reinikainen, M., Oasmaa, A. Solantausta, Y. (2015). "Co-processing of Dry Bio-oil, Catalytic Pyrolysis Oil, and Hydrotreated Bio-oil in a Micro Activity Test Unit". Energy \& Fuels, Vol. 29, No. 6, pp. 3707-3714. https://doi.org/10.1021/acs.energyfuels.5b00339

[41] De Miguel Mercader, F., Groeneveld, M. J., Hogendoorn, K., Kersten, S. R. A., Way, N. W. J., Schaverien, C. J. (2010). "Production of advanced biofuels: co-processing of upgraded pyrolysis oil in standard refinery units". Applied catalysis B: Environmental, Vol. 96, No. 1-2, pp. 57-66. https://doi.org/10.1016/j. apcatb.2010.01.033

[42] Van Rossum, G., Kersten, S. R. A., Van Swaaij, W. P. M. (2007). "Catalytic and noncatalytic gasification of pyrolysis oil". Ind. Eng. Chem. Res., Vol. 46, pp. 39593967. https://doi.org/10.1021/ie061337y

[43] Czernik, S., French, R., Feik, C., Chorine, E. (2002). "Hydrogen by Catalytic Steam Reforming of Liquid Byproducts from Biomass Thermoconversion Processes". Ind. Eng. Chem. Res., Vol. 41, pp. 4209-4215. https://doi.org/10.1021/ie020107q

[44] Jones, S. B., Valkenburg, C., Walton, C., Elliott, D. C., Holladay, J. E., Stevens, D. J., Kinchin, C., Czernik, S. (2009). "Production of Gasoline and Diesel from Biomass via Fast Pyrolysis, Hydrotreating and Hydrocracking: A Design Case". Pacific Northwest National Laboratory, USA. Tech. Rep. PNLL - 18284. https://doi. org/10.2172/949907

[45] Henrich, E., Dahmen, N., Dinjus, E. (2009). "Cost estimate for biosynfuel production via biosyncrude gasification". Biofuels, Bioproducts and Biorefining, Vol. 3, No. 1, pp. 28-41. https://doi.org/10.1002/bbb.126

[46] Lin, C. Y. (2013). "Effects of biodiesel blend on marine fuel characteristics for marine vessels". Energies, Vol. 6, pp. 4945-4955. https://doi.org/10.3390/ en6094945 